
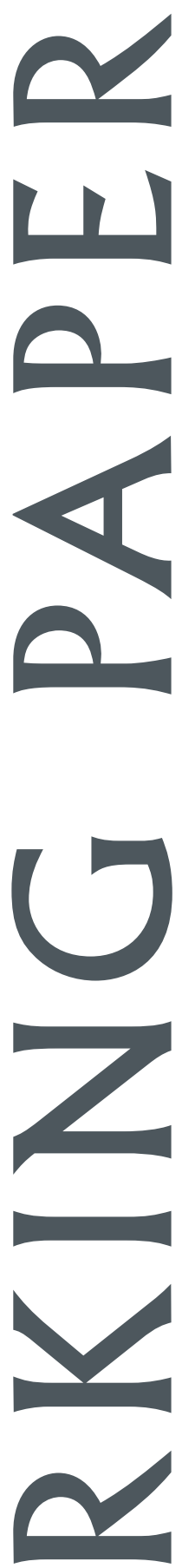

EAST-WEST CENTER 
The U.S. Congress established the East-West Center in 1960 to foster mutual understanding and cooperation among the governments and peoples of the Asia Pacific region including the United States. Funding for the Center comes from the U.S. government with additional support provided by private agencies, individuals, corporations, and Asian and Pacific governments.

East-West Center Working Papers are circulated for comment and to inform interested colleagues about work in progress at the Center.

For more information about the Center or to order publications, contact:

Publication Sales Office

East-West Center

1601 East-West Road

Honolulu, Hawaii 96848-1601

Telephone: 808-944-7145

Facsimile: 808-944-7376

Email: ewcbooks@EastWestCenter.org

Website: www.EastWestCenter.org 


\title{
How Sustainable are Benefits from Global Production Networks? Malaysia's Upgrading Prospects in the Electronics Industry
}

\author{
Dieter Ernst
}

Dieter Ernst is a Senior Fellow and Theme Leader for economic studies at the East-West Center. Dr. Ernst's previous affiliations include the OECD, Paris (as senior advisor), the Berkeley Roundtable on the International Economy (BRIE), and University of California at Berkeley (as research director). Dr. Ernst co-chairs an advisory committee for the U.S. Social Science Research Council to develop a new program on Asia. He serves on the Committee on Information Technology and International Cooperation (ITIC) of the U.S. Social Science Research Council and on the Committee established by the Prime Minister's Science Advisor to set up a National Science Foundation for Malaysia. Dr. Ernst has published numerous books and articles in leading journals on information technology, globalization, and economic growth. Recent books include International Production Networks in Asia: Rivalry or Riches?, and Technological Capabilities and Export Success: Lessons from East Asia.

This paper is forthcoming in: "Global Production Networks and Industrial Upgrading: Malaysia's Electronics Industry," in Kidd, J. and F.J. Richter (eds.), Trust and Anti-Trust in Cross-Cultural Alliances, published for the World Economic Forum, Palgrave, London.

East-West Center Working Papers: Economics Series reports on research in progress. This paper has been peer-reviewed. The views expressed are those of the author and not necessarily those of the Center. Please direct orders and requests to the East-West Center's Publication Sales Office. The price for Working Papers is $\$ 3.00$ each plus postage. To destinations within the U.S. and its territories: for surface mail, add $\$ 3.00$ for the first paper plus $\$ 0.75$ for each additional title or copy sent in the same shipment; for airmail, add $\$ 4.00$ for the first paper plus $\$ 1.25$ for each additional title or copy sent in the same shipment. To destinations elsewhere: for surface mail, add $\$ 6.00$ for the first paper plus $\$ 1.50$ for each additional title or copy sent in the same shipment; for airmail, add $\$ 7.50$ for the first paper plus $\$ 3.50$ for each additional title or copy sent in the same shipment. 
"One of the most striking features of the $21^{\text {st }}$ century is that everything has become tradable", John Plender, Going off the rails: global capital and the crisis of legitimacy, 2003

"The world is more US-centric now than it has ever been", Stephen Roach, chief economist of Morgan Stanley, at the World Economic Forum 2003

"One of the important issues to be examined is whether and to what extent intraregional trade and investment linkages will work as a major factor of growth in the future", Ivan Tselichtchev, in this volume

\section{Introduction}

A progressive integration of East Asia's electronics industries into global production networks (GPNs) provides a fascinating example of the benefits that Asian firms can reap from linkages with foreign firms (e.g., Borrus, Ernst, Haggard, 2000; Ernst, 1997a). Network participation has provided Asian producers with access to the industry's main growth markets, helping to compensate for the initially small size of their domestic markets. It also provided new employment opportunities, and induced Asian network suppliers to develop primarily operational technological and management capabilities (Ernst and Kim, 2002). As a result, East Asia has emerged as the dominant global manufacturing base of the electronics industry, especially for assembly and component manufacturing.

However, the 1997 financial crisis, as well as the downturn in the global electronics industry since late 2000 have brutally exposed the downside of export-led 
industrialization: a country is more vulnerable, the more it is focused on assemblyintensive mass production of commodity-type products, and the higher the share of these electronics products in its exports. This has given rise to an important debate that should inform the study of trust and anti-trust in cross-border corporate networks, especially those networks that include companies from Asian countries. Three questions are addressed in this debate:

1. Can earlier benefits from integration in GPNs be sustained?

2. Can these benefits be broadened to include improvements in learning, innovative capabilities and value-added?

3. What adjustments does this require in firm strategies and organization, and in related government policies?

This chapter argues that an upgrading of East Asia's electronics industry is an essential prerequisite for sustaining and broadening the benefits of integration into GPNs. Defined as a shift to higher value-added products, services and production stages through increasing specialization and efficient domestic and international linkages, industrial upgrading (IU) necessitates a strong domestic knowledge base. Successful upgrading raises daunting challenges, chief among them are substantial investments in long-term assets, such as specialized skills and innovative and research capabilities. In countries where the domestic industry structure provides only limited incentives for firms to invest in these long-term assets, upgrading prospects will remain limited.

This, of course, implies that "winners and losers will emerge and differentiation will increase" (Tselichtchev, in this volume). Yet, globalization based on increasing inequality is hardly a realistic proposition, as it gives rise to anti-trust, if not violence and 
wars. Conscious efforts are thus required to counter rising inequality. Business can contribute to these efforts. The keys to success are organizational innovations that help develop and disperse skills and capabilities ahead of what the market would provide. International knowledge sourcing through participation in GPNs, as well as through complementary linkages with foreign universities, consulting firms and through informal global peer group networks, can play an important catalytic role. These diverse international linkages can help Asian firms to bridge existing gaps in specialized skills and innovative capabilities; and they can facilitate changes in organization and procedures that are necessary to develop these capabilities locally.

It is difficult in one paper to consider the entire range of upgrading prospects through network participation that face the countries of East Asia. We focus on Malaysia $^{1}$, a mid-sized country that is confronted with a particularly demanding challenge, due to three peculiar characteristics of its electronics industry:

First, Malaysia exceeds most other Asian electronics producers (with the exception of Singapore) in terms of its exposure to GPNs. Electronics constitutes around $60 \%$ of Malaysia's exports. The electronics industry is the major recipient of FDI, absorbing more than one third of total manufacturing FDI between 1996-98 (MIDA, 1999) ${ }^{2}$. And the US market absorbs $25 \%$ of Malaysia's total exports (an estimated $40 \%$ for electronics exports).

Second, with the Penang Development Center, with its two industrial master plans, and with the Bill of Guarantees (developed for its Multimedia Super Corridor) Malaysia has

\footnotetext{
${ }^{1}$ For related studies on upgrading perspectives in Korea's and Taiwan's electronics industry, see Ernst, 1994, 2000, and 2001.
} 
developed one of the most aggressive sets of upgrading incentives for private companies (both foreign and domestic). And yet...

Third, despite such policies, we find a mixed balance of benefits from network integration. On the positive side, Malaysia experienced, within a relatively short period, a substantial capacity and international market share expansion for electronics products. And until the mid-1990s, employment generation was significant, accompanied by considerable growth in productivity. Since then, however, productivity growth has slowed down, while lay-offs have considerably increased. Low-end assembly operations continue to dominate. Most importantly, Malaysia has failed to develop a sufficiently diversified and deep industrial structure, to induce a critical mass of corporate investment in specialized skills and innovative capabilities. In short, Malaysia's experience in the electronics industry indicates that nothing is automatic about benefits from participating in GPNs.

Section 1 in this chapter introduces an operational definition of industrial upgrading (IU). Section 2 sketches key characteristics of GPNs and documents the emergence of complex, multi-tier "networks of networks" which provide new opportunities for IU, but which also raise threshold requirements for participating in these networks. In section 3, we highlight structural weaknesses of the Malaysian electronics industry that constrain its upgrading prospects; assess current policies that try to link cluster development and global network integration; and ask to what degree linkages with contract manufacturers $(\mathrm{CMs})$ can broaden network benefits. Section 4

\footnotetext{
${ }^{2}$ Around 100 large foreign affiliates effectively dominate this industry. Their share in manufactured exports (most of it electronics), has increased sharply from 39.8\% in 1985 to $68.3 \%$ in 1992 (Takeuchi, 1997: p.9).
} 
concludes, by exploring new opportunities for international knowledge sourcing that could complement Malaysia’s linkages with GPNs.

\section{Industrial Upgrading}

An appropriate long-term development strategy for Asian electronics industries must focus on improvements in specialization, productivity, and linkages (as defined by Hirschman, 1958, chapter 6), all of which necessitate a broad base of skills and innovative capabilities. All four elements are essential prerequisites for improving a country's capacity to raise long-term capital that is necessary for facility investment, $\mathrm{R} \& \mathrm{D}$, and human resource development. The concept of industrial upgrading (IU) ties these four elements together (Ernst, 2003 d).

Our definition emphasizes the importance of international linkages. We do not assume that IU ends at the national border, and that it occurs only if improved specialization generates pressures to create dense forward and backward linkages within the district or the national economy. A "closed economy" assumption is unrealistic. First, as globalization and information technology (IT) have drastically increased the international mobility of trade, investment, and even knowledge (Ernst, 2003a and b), this increases the scope for cross-border forward and backward linkages (Ernst, 2002 a and $2003 \mathrm{c})$.

Second, most countries are constrained by a narrow domestic knowledge base and limited linkages. Both constraints are particularly important for Asian developing economies (e.g, Lall, 1997; Ernst, Ganiatsos, and Mytelka, 1998). With but few exceptions, highly heterogeneous economic structures constrain agglomeration economies; weak and unstable economic institutions obstruct learning efficiency; and a 
high vulnerability to volatile global currency and financial markets constrain patient capital that is necessary for the development of a broad domestic knowledge base. As a result of this "vicious circle", very limited sharing and pooling of resources and knowledge occurs within the country, and often even within the export-oriented cluster. To compensate for their narrow domestic knowledge base and limited linkages, Asian developing economies thus have to rely on foreign sources of knowledge to catalyze domestic capability formation. International linkages need to prepare the way for an upgrading of East Asia's electronics industries. Integration into GPNs is one possible approach.

\section{Global Production Networks}

\subsection{Characteristics}

Trade economists have recently discovered the importance of changes in the organization of international production as a determinant of trade patterns (e.g., Feenstra, 1998; Jones and Kierzskowski, 2000; Navaretti, Haaland, Venables, 2002). Their work demonstrates that

(i) Production is increasingly "fragmented" with parts of the production process being scattered across a number of countries, hence increasing share of trade in parts and components; and

(ii) Countries and regions which have been able to become a part of the global production network are the ones which have industrialized the fastest.

This chapter builds on this work, but uses a broader concept of GPNs that emphasizes four characteristics $^{3}$ : i) scope: GPNs encompass all stages of the value chain,

\footnotetext{
${ }^{3}$ For details, see Ernst, 1997, 2002a, 2003a, 2003b, and 2003c.
} 
not just production; ii) asymmetry: flagships dominate control over network resources and decision-making; iii) knowledge diffusion: the sharing of knowledge is the necessary glue that keeps these networks growing; and iv) information systems: the increasing use of digital information systems to manage these networks enhances not only information exchange, but also provide new opportunities for the sharing and joint creation of knowledge.

Vertical specialization has been a powerful driver of these networks (Ernst, 2002b). A GPN covers both intra-firm and inter-firm transactions and forms of coordination: it links together the flagship's own subsidiaries, affiliates and joint ventures with its subcontractors, suppliers, service providers, as well as partners in strategic alliances. A network flagship like IBM or Intel breaks down the value chain into a variety of discrete functions and locates them wherever they can be carried out most effectively, where they improve the firm's access to resources and capabilities and where they are needed to facilitate the penetration of important growth markets. The main purpose of these networks is to provide the flagship with quick and low-cost access to resources, capabilities and knowledge that are complementary to its core competencies. As the flagship integrates geographically dispersed production, customer and knowledge bases into GPNs, this may produce transaction cost savings. Yet, the real benefits result from the dissemination, exchange and outsourcing of knowledge and complementary capabilities.

Knowledge sharing is the glue that keeps these networks growing. Flagships need to transfer technical and managerial knowledge to local suppliers. This is necessary to upgrade the suppliers' technical and managerial skills, so that they can meet the technical 
specifications of the flagships. Originally this involved primarily operational skills and routine procedures required for sales and distribution, manufacturing and logistics. Over time, knowledge sharing also incorporates higher-level, mostly tacit forms of "organizational knowledge" required for control, coordination, planning and decisionmaking, as well as for learning and innovation.

\section{Flagships}

While equity ownership is not essential, network governance is distinctively asymmetric. There is thus an inherent trend towards inequality that may constrain the building of trust. A GPN typically consists of various hierarchical layers, ranging from network flagships that dominate such networks, due to their capacity for system integration (Pavitt, 2002), down to a variety of usually smaller, local specialized network suppliers. The flagship is at the heart of a network: it provides strategic and organizational leadership beyond the resources that, from an accounting perspective, lie directly under its management control (Rugman and D'Cruz, 2000). The strategy of the flagship company thus directly affects the growth, the strategic direction and network position of lower-end participants, like specialized suppliers and subcontractors. The latter, in turn, have no reciprocal influence over the flagship strategy. The flagship derives its strength from its control over critical resources and capabilities that facilitate innovation, and from its capacity to coordinate transactions and knowledge exchange between the different network nodes.

Flagships retain in-house activities in which they have a particular strategic advantage; they outsource those in which they do not. It is important to emphasize the diversity of such outsourcing patterns. Some flagships focus on design, product 
development and marketing, outsourcing volume manufacturing and related support services; other flagships even outsource a variety of high-end, knowledge-intensive support services.

\section{Asian suppliers}

To understand how sustainable benefits are from integration into GPNs, it is necessary to open the black box of "Asian suppliers" (Ernst, 2003e). First, some of these suppliers have been around for quite a while. Since the 1960s, various groups of Asian suppliers have emerged, first in consumer electronics, then as contract chip assemblers (Korea's Anam as the most prominent example) and, more recently, in contract wafer fabrication ("silicon foundries"): or as ODM suppliers of computers and related equipment, IC design houses, and suppliers of PDA and wireless devices. Second, Asian suppliers obviously differ considerably in their capabilities, network position and market power. Substantial differences also exist with regard to their capacity for component sourcing, design \& development and engineering, their capacity to provide global support services, and their use of digital information systems.

Greatly simplifying, we distinguish two types of Asian suppliers: higher-tier and lower-tier suppliers. "Higher-tier” suppliers, like for instance Taiwan's Acer group, play an intermediary role between global flagships and local suppliers. They deal directly with global flagships (both "brand leaders" and global US-based "contract manufacturers"); they possess valuable proprietary assets (including technology), which enables them to contract out the manufacturing of parts or final products based on their own design; they also provide knowledge support services to foreign firms; and they have developed their own mini-GPNs (e.g., Chen, 2002). 
These higher-tier suppliers are now under pressure to develop complementary skills and capabilities in new product introduction (NPI), process re-engineering, as well as in "embedded" software, SOC (system-on-chip) design, IP trade, system integration, and become involved in the management of network resources, supply chains and customer relations. With the exception of hard-core R\&D and strategic marketing that remain under the control of the global brand leader, Asian higher-tier suppliers must be able to shoulder all steps in the value chain. They must even take on the coordination functions necessary for global supply chain management.

"Lower-tier" Asian suppliers are the weakest link in the GPNs. Their main competitive advantages are low cost and speed, and flexibility of delivery. Typically, they use dedicated parts supplied by a foreign firm, or contract manufacture parts or final products to the specifications of a foreign firm. These lower-tier suppliers are often used as "price breakers" and "capacity buffers", and can be dropped at short notice. This second group of local suppliers rarely deals directly with the global flagships; they interact primarily with local higher-tier suppliers. Lower-tier suppliers normally lack proprietary assets, their financial resources are inadequate to invest in training and $R \& D$ and they are highly vulnerable to abrupt changes in markets and technology and to financial crises.

\subsection{Networks of Networks: Outsourcing Based on Contract Manufacturing ${ }^{4}$}

To move this model a bit closer to reality, we distinguish two types of global flagships: i) "Original equipment manufacturers" (OEMs) who derive their market power from selling global brands, regardless of whether design and production is done in-house

\footnotetext{
${ }^{4}$ Based on Ernst, 2003 e.
} 
or outsourced; and ii) U.S.-based global "contract manufacturers" (CMs) who, over the last few years, have aggressively developed their own GPNs to provide integrated manufacturing and global supply chain services to the OEMs.

This gave rise to an extremely rapid growth of the CM industry. From 1996 to 2000, capital expenditures grew 11 -fold (50\% CAGR), and revenues increased by almost $400 \%$ ( $81 \%$ CAGR). The industry's rapid growth was driven primarily by M\&A. Outsourcing based on contract manufacturing has created increasingly complex, multitier "networks of networks" that juxtapose global ties among the two large global players (the OEMs and CMs), as well as intense regional ties with, mostly smaller, Asian firms ${ }^{5}$.

Sturgeon and Lester (2003) emphasize that the rise of U.S. contract manufacturers with global reach may pose a serious competitive threat to Asian suppliers in four areas: component sourcing; design, development and engineering (D\&D\&E); "global reach" which is the provision of support services across multiple locations in all major macroregions; and finally, "network coordination" giving improved network efficiencies through the use of sophisticated digital information systems.

Our analysis leads us to a more or less optimistic perspective. It is important to emphasize the still limited share of US contract manufacturers in worldwide electronics hardware production. In 2001, this share was estimated to be around $13.7 \%$ (up from $13.0 \%$ in 2000). For 2002, this share is projected to increase to $16.3 \%$ (email from Eric Miscoll, CEO, Technology Forecasters, Inc, April 15, 2002). Clearly, the US model of contract manufacturing is just one possible approach, and Asian electronics firms will

\footnotetext{
${ }^{5}$ A focus on complex, multi-tier "networks of networks" distinguishes our analysis from Sturgeon's modular production network model (2002).
} 
continue to play an important role, based on their accumulated experience, in this form of contract manufacturing [before it was given that name] (Ernst, 1997).

This learning process goes back to the early 1980s: well-documented milestones are Samsung's contract with GE to act as its global contract manufacturer for microwave ovens (Magaziner and Patinkin, 1989); the spread of OEM (original equipment manufacturing) contracts from Korea's consumer electronics industry to Taiwan's computer industry and their gradual transformation into ODM (original design manufacturing) contracts (e.g., Ernst and O’Connor, 1992, chapter 4; Hobday, 1995; Ernst, 2000); and the market leadership by Asian, primarily Taiwanese, silicon foundries in contract wafer fabrication (Chen, 2002). Given this long history of contract manufacturing in Asia, there are ample opportunities to groom a variety of new specialized Asian suppliers, provided necessary changes are put in place in policies and support institutions. Let us now look at these efforts in Malaysia.

\section{Implications for Malaysia's Upgrading Perspectives in the Electronics Industry}

A progressive integration into global production networks (GPNs) has been a primary driver of Malaysia's success in the electronics industry. This integration started in the early 1970s with offshore chip assembly, primarily by US semiconductor firms. The next stage, since the early 1980s, was centered on Japanese electronics makers that moved their export platform production for consumer electronics to Malaysia and other Southeast Asian locations. Since the late 1980s, Malaysia was integrated into the production networks of American producers of computer-related equipment, as well as those established by their Taiwanese subcontractors. The most recent stage involves the 
production of communication and networking equipment, and the acquisition of existing affiliates of global brand leaders (the so-called OEMs) by global contract manufacturers (CMs).

The results have been impressive, in terms of production, exports, employment and investment. During the last decade, from 1990 to 2000, Malaysia's electronics industry registered a CAGR of $23.5 \%$. During the same period, exports grew at an annual average of $25.2 \%$, while employment grew almost $11 \%$ annually until 1995 (figures courtesy of Ministry of International Trade and Industry, Kuala Lumpur).

\subsection{Structural Weaknesses}

Yet, despite these achievements, a shift in strategy is now overdue. Seven structural weaknesses of Malaysia's electronics industry constrain its upgrading prospects (Ernst, 2003e):

First, Malaysia's integration into GPNs gave rise to the development of an asymmetric industry structure in which multiple layers of electronics firms are distinguished by unequal control over resources and decision-making. While Malaysian firms dominate in numbers, Malaysia's electronics industry continues to be shaped by strategic decisions of global flagships (both OEMs and major American CMs). In hierarchical order, four types of firms can be distinguished: at the top of the industry pyramid are global OEMs and CMs; followed by suppliers and contract manufacturers from Taiwan, Japan, Singapore, and Korea; higher-tier local suppliers; and, at the bottom, lower-tier local suppliers.

Second, there is a heavy reliance on technological capabilities developed within affiliates of global flagships, and their eventual spill-overs into local firms. This 
traditional pattern of network integration apparently produces decreasing benefits. A good proxy is the disturbing slow-down in productivity growth since 1995. In Penang, for instance, total factor productivity (TFP) of manufacturing declined by $-0.5 \%$ between 1995 and 1997, compared to an increase of 8.9\% between 1990 to 1995 (State Government of Penang, 2001). In the electronics industry, TFP growth fell to $2 \%$ (from $14.1 \%$ during the earlier period) - hardly sufficient for an industry that is supposed to be the engine of upgrading ${ }^{6}$.

Third, in contrast to countries like Taiwan, South Korea and Singapore, Malaysia has failed to develop a broad and multi-tier base of support industries. The majority of the local suppliers possess few proprietary advantages and clearly qualify as "lower-tier" suppliers $^{7}$. The result is a lack of efficient domestic linkages and an inverted production pyramid -- a huge and rapidly growing final product sector that rests on a weak and much smaller domestic base of support industries.

Fourth, a further consequence of Malaysia's truncated industry structure is a persistently high import dependence stemming from rapid growth in the final products sector which necessitates considerable imports of intermediates and production equipment. By the late 1980s, the Malaysian electronics industry had to import almost $43 \%$ of the intermediate goods that were required for the production of one unit of final output, far more than Korea (37\%) and Japan (8.2\%) (Takeuchi, 1997:7). Malaysia's

\footnotetext{
${ }^{6}$ As for TFP growth for all of Malaysia, most estimates put it around 1 to $2 \%$ p.a. (until 2000). This is way below the minimum TFP growth projected by the government of 3.2\% (for the period 2001 to 2010), which is necessary, if Malaysia wants to achieve the projected growth rate of $7.5 \%$. Compared with historical growth patterns of productivity in industrialized countries, such a massive slow-down in TFP growth is certainly premature, in light of the thus far still limited progress in Malaysia's specialization by product and production stage.
} 
dependence on imports of electronics components, and especially semiconductors kept increasing during the 1990s, both as a share of electronics imports, and as a share of total merchandise imports ${ }^{8}$.

Fifth, a focus on low-end assembly operations for a handful of products adds further to the country's vulnerability, as those operations can be easily replicated in countries with low labor costs.

Sixth, of particular concern, is a declining capacity for employment generation. Following earlier downturns a substantial share of laid-off workers were re-hired, but this no longer seems to be the case ${ }^{9}$. This shows that export-led electronics manufacturing is unlikely to act again as an engine of employment growth.

Finally, an increasingly important weakness in Malaysia's electronics industry is a serious mismatch between the demand and supply for skills. Despite the recession, job vacancies have kept increasing, with the biggest job openings in the "managerial and professional" categories in the electronics industry. This human resource bottleneck also has an important qualitative dimension. There is a widespread perception among electronics firms that local university graduates have book knowledge, but are illequipped to deal with real world problems on the shop floor, and that they lack basic skills in communication, negotiation and presentation. This has led to the emergence of a bifurcated labor market, where the winners pick all the stakes - resulting in intense

\footnotetext{
${ }^{7}$ There are of course a few widely quoted success cases, almost all of them located in Penang, such as BCM, Globetronics, Unico, LKT, and Eng Teknologi, that have successfully positioned themselves as higher-tier local suppliers for leading OEMs (e.g., Rasiah, 1995; Best, 2001).

${ }^{8}$ This suggests a fundamental mismatch of the country's electronics exports and imports, with negative terms-of-trade implications: while imports involve high value-added core components, especially microprocessors and other ICs, Malaysia's component exports overwhelmingly consist of low-value added final assemblies.
} 
competition for those engineers and managers who either graduated from overseas universities or who have worked for a foreign firm.

\subsection{The Second Industrial Master Plan: Clusters and Global Network Integration}

An important attempt to overcome the above weaknesses is the Second Industrial Master Plan (IMP2) (Ministry of International Trade and Industry, 1996). This document signals a fundamental change in Malaysia's industrialization strategy, away from assembly-based "outward industrialization" to value chain-based manufacturing, from sector-based to cluster-based development, and from performance targets to productivitydriven growth. The strategy is defined by two key concepts: "manufacturing ++" and “cluster-based development". In line with Porter (1990), “manufacturing ++" highlights activities at both ends of the value chain, i.e. 'R\&D and engineering and in-bound logistics' on the one hand and 'outbound-logistics and sales \& marketing' on the other hand. It is argued that a move into knowledge-intensive support services like product development, process engineering, supply chain management, and some select areas of R\&D will enhance local value-added and productivity. "Cluster-based development" implies that, based on existing strengths especially in components and semiconductors, developing a dense web of domestic linkages will enhance value-added and deepen domestic capabilities. The IMP2 highlights four specific objectives:

i) foster the growth of "leading local companies (Malaysian brands);

ii) reduce dependence on input imports;

\footnotetext{
${ }^{9}$ In Penang, almost two third of the retrenched workers in the electronics industry (ca. 16,000, primarily low-skilled, female production workers), have left the labor market, indicating a massive return of Malay females (in the 25-29 age range) to their villages (Too and Leng, 2002).
} 
iii) strengthen agglomeration economies by developing "Integrated Manufacturing Centers" (IMC) for global network flagships;

iv) develop cross-border clusters.

Of these, the first two objectives are problematic, while the last two indicate a move in the right direction ${ }^{10}$.

Take recent developments in the Penang cluster where an attempt is made to combine the third and the fourth objectives of the IMP2. Rather than just giving in to requests for improved incentives by foreign companies, the state government pursues a more selective approach: incentives are explicitly linked with the promotion of “integrated manufacturing centers" (IMC). The goal is to induce global flagships to move to Penang an "entire chain of operations for a particular product". It is expected that this should enable the Penang cluster to upgrade from mere assembly and testing to knowledge support services, like sales and marketing, adaptive process engineering and tooling, financial planning, and, eventually parts of R\&D like design and development (D\&D).

\subsection{Linkages with OEMs: Fragile Upgrading Prospects}

The outcome of policies to upgrade linkages with OEMs however depends on sector-specific developments that are beyond the control of a mid-sized country like Malaysia. The decisions, for instance, by Komag and Quantum, to relocate their entire

\footnotetext{
${ }^{10}$ The first objective represents an outdated concept of IU that assumes a fixed sequencing pattern from low-end, assembly-type subcontracting to "original brand name" (OBM) manufacturing (for a typical example, see Hobday, 1995). We now know that the transition to OBM is extremely difficult - even Taiwan's Acer group has had only limited success (Ernst, 2000). The limited achievements of the "Proton City cluster" in automobiles also indicate that this objective may be unrealistic. As for the second objective, much depends on whether the country succeeds in finding the right balance between reaping the benefits of foreign input imports (as described in Rodrik, 1999) and the development of local backward and forward linkages.
} 
U.S. manufacturing operations to Penang, primarily reflects the relentless pressure within the hard disk drive industry to move volume manufacturing and support services to locations having close proximity to Singapore which is the dominant global cluster center for these activities (Ernst, 1997).

A major constraint to the building of trust is that much of Malaysia's inward FDI remains highly "footloose" and prone to sudden relocation decisions to lower-cost locations. Equally important is that global flagships that are forced to downsize to retain shareholder value in a recession are inclined to cut first the employment in export platform locations, which reflect their flexible labor market regulations. These developments are hardly conducive for fostering trust between Malaysian and foreign firms. Take two prominent examples. For instance, Quantum's decision in 2001 to move to Penang its entire manufacturing line for digital linear tape storage devices was very short-lived. One year later, in the summer of 2002, Jabil, the global contract manufacturer, was about to acquire Quantum's tape drive manufacturing activities as well as two low-end products of the tape automation product division (author's interviews in Malaysia, July 2002)

Or take the recent decision by Dell to relocate its desktop production for the Japanese market from Penang to Xiamen, China, and to assign Xiamen to be the exclusive supply base for Dell's complete Chinese product line - while Dell's two plants in Penang remain the BTO shipment hub for the rest of its Asia-Pacific market (with the exception of desktops). This constitutes a major blow for Malaysia. While immediate job losses are only 60 (out of a total of 2000), this move to China indicates that more such redeployments may be in the offing. Dell gives three reasons for its 
decision to redeploy to China: good and low-cost Chinese engineers; cheap land; and the too limited number of flight connections between Malaysia and Japan. This further indicates the unpredictability and fragility of Malaysia's GPN-induced upgrading prospects.

Even so, linkages to OEMs also provide important new upgrading opportunities. Take the attempts to promote the adoption of Rosetta Net e-business standards ${ }^{11}$ to improve the network integration of Malaysian suppliers. The idea is to involve major global network flagships that are already on the RosettaNet, such as Cisco, Dell, Quantum, Siemens, Solectron, Intel, AMD, Hitachi, Agilent, and Motorola. These flagships could then be used to pressure and cajole their local suppliers to upgrade their IT infrastructure so that these local suppliers become eligible for the above grants. It is however an open question of how the substantial constraints that prevent smaller lowertier suppliers can be overcome for them to adopt the RosettaNet standards ${ }^{12}$.

\subsection{Developing Multiple Linkages with Contract Manufacturers}

To what degree can linkages with contract manufacturers (CM) broaden Malaysia's upgrading prospects? Three developments are important: the arrival of major

\footnotetext{
${ }^{11}$ RosettaNet is a global consortium of over 400 of the world's leading OEMs and CMs for electronic components, semiconductors, computers and telecommunications equipment, working to create, implement and promote open e-business process standards. Malaysia is the fifth country in Asia to join RosettaNet, after Japan, Korea, Singapore, and Taiwan.

${ }^{12}$ Participation in the definition of the RosettaNet standards is probably the more immediate benefit. Six Malaysian electronics engineers, on loan to RosettaNet for two years, will work for six months at the California-based RosettaNet headquarters alongside American engineers to define XML-based specifications for the global electronics industry. The companies that provide these Malaysian engineers include global flagships (Intel and Microsoft), leading local suppliers (BCM Electronics, Globetronics Multimedia Technology), and two employees of MIMOS (= Malaysian Institute of Microelectronics Systems), a web developer and a public key infrastructure developer. Obviously, these six Malaysian engineers will play an important role as multipliers and upgrading catalysts, once they return from their US mission. They will also act as gatekeepers for these more knowledge-intensive linkages with global flagships.
} 
US CMs; the mutation of component suppliers from Japan and Taiwan into contract manufacturers; and upgrading efforts of Malaysian higher-tier suppliers.

\section{a. Arrival of major US CMs}

All the main US CMs are now present in the Northern Penang/Kulim Hi-Tech cluster, or in the southern Johor/Singapor cluster ${ }^{13}$. Thus far, this has created only limited upgrading opportunities, insufficient for a major push into more knowledge-intensive activities (Ernst, 2003e). The main benefits are an increasing sophistication in assembly technologies (especially multi-tier SMT, used for PCBA), and the provision of support services related to manufacturing, with the exception of asset and logistics management ${ }^{14}$. The purpose of these services is to provide manufacturing solutions that enable a quick ramping-up of volume manufacturing.

Overwhelmingly, global CM players keep design (and especially circuit, advanced optical and systems design) concentrated in the US and Europe. One would of course expect such a disparity in design and product development, due to their high knowledge-intensity. This however is now beginning to change, as Taiwanese contract manufacturers are aggressively expanding their design-based ODM services ${ }^{15}$.

\section{b. Component suppliers from Japan and Taiwan}

\footnotetext{
${ }^{13}$ Solectron is present in Penang, Johor and Singapore; Flextronics in Singapore and Johor; Sanmina/SCI in Penang, and Singapore; Celestica in Kedah`s Kulin Hi-tech Park; and Jabil Circuit in Penang. There are also a few important investments elsewhere in the region, such as Malaysia`s Kuching/Sarawak (Sanmina/SCI), Thailand (Flextronics, Sanmina/SCI and Celestica), and Indonesia (Celestica).

14 Typically, this also includes electrical and mechanical design services, global test services, printed circuit board layout services and detailed process engineering ("advanced manufacturing technology research" in CM industry parlance).

15 Increasingly, certain types of electronic design, including SOC (system-on-chip) design, have been relocated to some of the leading IT clusters in the Asia-Pacific region that provide a skilled and re-trainable workforce as well as easy access to foundry, assembly and testing services. Design first moved to Taiwan and Korea, but now is moving also to China and India, as well as to Singapore and Malaysia (Ernst, 2003f)
} 
A second important development in fact predates the arrival of American contract manufacturers that has absorbed most public attention. Both the parts and the component suppliers from Japan and Taiwan, whose arrival in Malaysia goes back to the second part of the 1980s, have acted as catalysts for the development of Malaysia's local support industries (e.g., Takeuchi, 1993, and Ernst, 1997). Generally the Japanese component manufacturers have been concentrated primarily in the consumer electronics sector, although some of them, however, have also branched out into the computer sector.

Taiwanese firms have played an important role in Malaysia's computer industry since the late 1980s. Over time, their Malaysian affiliates have upgraded from simple volume manufacturing, according to designs owned by the global flagships, and to more sophisticated contract-manufacturing services for leading computer network flagships. Large Taiwanese contract manufacturers have pioneered the use of original design for manufacturing (known as ODM) capabilities in Asia. This may provide upgrading opportunities for Malaysian firms that interact with affiliates of these Taiwanese contract manufacturers.

\section{c) Upgrading Efforts of Malaysian Higher-tier Suppliers}

Leading higher-tier local suppliers understand that they need move up within the hierarchy of contract manufacturing arrangements, from low-end box build, and consignment arrangements, to ODM provision, and then to total solutions provider (author's interviews in Malaysia, July 2002). They are however facing major problems in sustaining and expanding their upgrading efforts. They all face the demanding challenge of pursuing simultaneously the following five upgrading strategies, each of which requires major investments: 
- to establish themselves with a credible position as low-cost niche contract manufacturers (CMs)

- to develop global presence through overseas FDI

- to develop diversification and market segmentation,

- to develop knowledge-intensive support services,

- to invest in design and R\&D.

The implementation of these upgrading options requires the development of a broad and diverse set of capabilities. It is important to emphasize the systemic nature of the required capabilities ${ }^{16}$. Take manufacturing services. The move from PCBA and box build to test necessitates the development not only of testing capabilities (which are scarce), but also of system engineering and maintenance capabilities. Furthermore, developing design \& engineering capabilities requires substantial funds for R\&D. Or take after-ship services. A seemingly mundane activity like repair requires the training of technicians in failure analysis, while end-life program management requires capable supply chain managers. As for the upgrading of procurement and outbound logistics, substantial funds are required for the gradual upgrading of the necessary information systems.

The successful upgrading of Malaysian higher-tier suppliers requires fundamental changes in industry organization, i.e. a transition toward flexible domestic supplier networks that can complement the capabilities of individual Malaysian suppliers. Second, the quality of human resources needs to be improved, through a constant process of re-

\footnotetext{
${ }^{16} \mathrm{LC}$, one of the most successful local companies, for instance attempts to build on existing strengths in contract manufacturing and the provision of ODM services, to become a lower-cost "total solution provider" for carefully chosen niche markets. To do this with low overheads requires strong capabilities in
} 
skilling and re-learning. And, third, international knowledge sourcing is required to bridge existing gaps in specialized skills and innovative capabilities, and to facilitate changes in organization and procedures that are necessary to develop these capabilities locally.

\section{New Opportunities: International Knowledge Sourcing}

\subsection{The MSC concept}

A widely known attempt to address this issue is the government's initiative to establish a $\$ 40$ billion Multimedia Super Corridor (MSC) that was supposed to leapfrog the country into fully developed nation status by the year 2020 (Multimedia Development Corporation, 2002). In 1996, the government had hired McKinsey, the global consulting firm, to draft a blueprint for a 15-kilometer-by-50-kilometer strip intended to be Malaysia's answer to Silicon Valley. An unprecedented set of incentives, enshrined in the Bill of Guarantees, were offered to companies involved in the creation, distribution, integration or application of multimedia products and services within the $\mathrm{MSC}^{17}$.

$\$ 3.7$ billion have been spent thus far, but results are disappointing. A leaked confidential report by the very same company that designed the project (McKinsey) concluded in February 2001 that the Multimedia Super Corridor " had not attracted much

six highly interdependent functions: manufacturing, quality, materials, procurement, engineering and human resources.

${ }^{17}$ According to the Multimedia Development Corporation (2002), these incentives include commitments "to provide a world-class physical and information infrastructure; to allow unrestricted employment of local and foreign knowledge workers; to ensure freedom of ownership by exempting companies with MSC Status from local ownership requirements; to give the freedom to source capital globally for MSC infrastructure, and the right to borrow funds globally; to provide competitive financial incentives, including Pioneer Status (100 percent tax exemption) for up to ten years, or an investment tax allowance for up to five years, and no duties on the importation of multimedia equipment; to become a regional leader in Intellectual Property Protection and Cyberlaws; to ensure no censorship on the Internet; to provide globally competitive telecommunications tariffs; to tender key infrastructure contracts to leading companies willing to use the MSC as their regional hub; and to provide a high-powered implementation agency to act as an effective one-stop super shop." 
interest from global investors, nor made an impact on the domestic economy." (Prystay, 2001). There is a growing recognition that lavish tax incentives and massive investment in infrastructure are insufficient to bring about the development of dynamic clusters. Recent strategic documents emphasize that the key to success are incessant efforts on a massive scale to continuously upgrade existing skills and capabilities, and to extend them into new areas like photonics, embedded software and chip design (National Information Technology Council, 2002).

The following major priority areas for reducing the skills mismatch in the Malaysian electronics industry were identified during recent interviews with government agencies and leading companies (June/July 2002):

1. A massive re-skilling and re-training of production workers;

2. An increase in the number of graduates, especially for EEE, IT, and circuit design who are able to combine hardware, software, and application knowledge;

3. Find experienced managers, especially for strategic marketing, and upgrade management in general, and the management of international linkages;

4. Find entrepreneurs that combine street-wise commercial and financial instincts with analytic capacity for strategic decision-making;

5. Find experienced and industry-savvy administrators who are willing to stick out their necks and to do more than just follow the rules (this of course requires some incentive alignment);

6. Create incentive alignments for university professors and academics that encourage close interaction with private sector (company internships and sabbaticals); 
7. Support intense interactions with expatriate nationals who are based in the US, Australia and Europe, or elsewhere in Asia;

8. Create a capacity to bring in at short notice specialized experts from overseas who can help bridge existing knowledge gaps and who can catalyze necessary changes in organization and procedures.

\subsection{Diversifying international linkages}

Malaysia should also exploit new opportunities for diversifying international linkages that can complement its integration into GPNs. First, the country needs to strengthen linkages with overseas universities that can help to upgrade research, development and design capabilities in Malaysian universities and public labs. The focus thus far has been on a handful of global elite institutions that bring in their standard, routine IT and business courses at very high cost. Instead, collaboration should focus on specific niche areas, in line with Malaysia's needs (e.g., chip design, embedded software, and photonics). The search should move beyond the exclusive ranks of the "Ivy League" universities: there is an ample choice of smaller, less well-known universities and research institutes that are more than willing to develop innovative courses that are customized to the specific needs and capabilities of Malaysia's electronics clusters.

Second, Malaysia should also reconsider its linkages with consulting firms. For information technology, the market is overwhelmingly dominated by a handful of giant corporations like IBM and consulting firms like Accenture that grew out of global accounting firms. These firms thrive on the economies of scale of knowledge sharing (called "network economies" by information economists). However, as flagships of global information service networks, these firms provide only a standard product 
wherever they go, and customization is possible only within certain limits within the standard solution package. This approach to customization is extremely costly: customers are charged for the time required to adjust the standard IT package and for effective implementation. And these costs are inflated by massive delays. The result is that new systems often come in late, over budget and unable to solve problems they were meant to address. This has created a demand for smaller, specialized niche players from Asia who do not start from standard solution packages and who offer clients fixed-price projects.

Third, Malaysia also needs to tap into an increasingly important carrier of international knowledge diffusion: "transnational technical communities" (Saxenian, 2002) of technically skilled immigrants with business experience and connections in the US, Europe and Japan that play an important and complementary role to network flagships in global production networks. By linking their home countries with the world's centers of information and communication technology (Silicon Valley, as well as other centers of excellence in less well known places like Helsinki, Kista/Stockholm, Grenoble, Munich, Tsukuba, Tel Aviv, etc) these informal social networks transform what used to be a one-way "brain drain" into a two-way process of "brain circulation". These networks could channel invaluable knowledge on global markets and technology trends to Malaysian electronics firms, complementing their linkages with global flagships. They also provide entrepreneurs and venture capitalists that can function well in both worlds.

In Malaysia, the Penang cluster has obviously benefited from students who have studied engineering and management overseas, whether in Singapore, Australia, Japan, the UK and the US, and who have returned with business experience and connections. Predominantly, these connections have been with global flagships like Intel and Motorola 
in semiconductors, or Matsushita and other Japanese flagships in consumer electronics. Overwhelmingly, the technology, skills, and knowledge generated by these immigrant engineers has focused on manufacturing-related activities. It is time now for Malaysia to adjust this "brain circulation" to encompass new areas like knowledge-intensive support services, software, circuit design and chip packaging. In short, international knowledge sourcing holds great promise as a necessary complement to integration into GPNs.

\section{CONCLUSIONS}

Based on operational definitions of industrial upgrading (IU) and global production networks (GPNs), this chapter has explored how Asian firms can benefit from inter-relations within these networks and through other forms of international knowledge exchange. Inherent in the hierarchical structure of flagship-dominated GPNs is a trend towards increasing inequality that may foster anti-trust, and hence erode possible benefits from globalization.

Focusing on Malaysia's electronics industry, we address three questions that are central to the study of trust and anti-trust in cross-border corporate networks:

1. Under what conditions can benefits from integration in GPNs be sustained?

2. Can these benefits be broadened to include improvements in learning, innovative capabilities and value-added?

3. What adjustments does this require in firm strategies and organization, and in related government policies?

We have documented that linkages with foreign firms through integration into GPNs provides new opportunities for upgrading Malaysia's electronics industry, but realizing 
this potential has also become more difficult for mid-sized countries like Malaysia. The best choice arguably is to move forward in incremental steps, and to build on existing strengths in assembly and volume manufacturing, by adding knowledge-intensive support services. Of critical importance is the absorptive capacity of the local suppliers, i.e. their resources, capabilities and motivations. To stay on the GPNs, local suppliers must constantly upgrade their absorptive capacity by investing in their skills and knowledge base.

Adequate incentives are required to generate sufficient investments in the development of skills and capabilities (as illustrated for instance by the Nordic countries in Europe, and by Taiwan, and Singapore). Successful IU within GPNs requires support policies for local firms through local supplier development, (co-funded) skill development, standards setting, and the provision of investment and innovation finance through a variety of sources and mechanisms, including venture capital, and IPOs.

Equally important are attempts to strengthen the country's innovative capabilities through selective international knowledge sourcing. As an immediate policy instrument, it is advisable to import missing critical skills from overseas. This could help to catalyze necessary reforms in the domestic innovation system.

Of critical importance for Malaysia's upgrading prospects in the electronics industry are new opportunities to tap into international flows of human capital and knowledge through informal peer group networks of technically skilled immigrants with business experience and connections in the US, Europe and Japan. These international social networks can play an important and complementary role as carriers of knowledge 
and capital to Malaysian firms that help sustain and expand benefits from integration into GPNs.

However, successful international knowledge sourcing necessitates a much stronger basis for mutual trust than appears to exist in the current hostile international environment. Tough new visa policies, introduced in the US, as well as in Europe and Japan, as part of the "war on terrorism", are beginning to stifle the mobility of knowledge, by constraining the movements of scientists, engineers, managers and students from countries like Malaysia. The damage caused to building trust in crossborder alliances is aptly summarized by Bill Reinsch, a former undersecretary of commerce in the Clinton administration: "One of our secret weapons has always been bringing people here to see what America is like. The ones that stay enrich our society and the ones that go back enrich their societies because they take our values with them. We're throwing all that away. The long-term consequences of this are horrible." (Financial Times, January 29, 2003: 11)

\section{REFERENCES}

Best, M., (2001) The New Competitive Advantage, Oxford University Press

Borrus, M., D. Ernst, and S. Haggard (2000), eds., International Production Networks in Asia. Rivalry or Riches?,_Routledge, London etc

Chen, Shin-Horng (2002), Global Production Networks and Information Technology: The Case of Taiwan, Industry and Innovation, 9 (3). Special issue on “Global Production Networks", guest editors: D. Ernst and Linsu Kim 
Ernst, D., (1994) What are the Limits to the Korean Model? The Korean Electronics Industry Under Pressure, A BRIE Research Monograph, The Berkeley Roundtable on the International Economy, University of California at Berkeley, Berkeley Ernst, D. (1997) From Partial to Systemic Globalization. International Production Networks in the Electronics Industry. Report prepared for the Sloan Foundation and jointly published as The Data Storage Industry Globalization Project

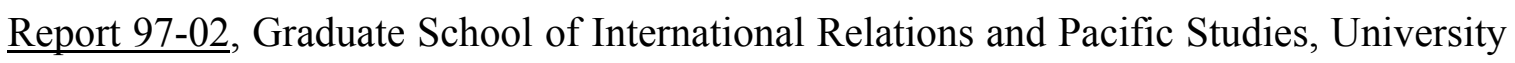
of California at San Diego

Ernst, D., (2000) Inter-Organizational Knowledge Outsourcing. What Permits Small Taiwanese Firms to Compete in the Computer Industry? Asia Pacific Journal of Management. Special issue on "Knowledge Management in Asia”, 17(2): 223-255,

Ernst, D., (2001) Catching-Up and Post-Crisis Industrial Upgrading. Searching for New Sources of Growth in Korea 's Electronics Industry, In Deyo, F., R. Doner and E. Hershberg (eds), Economic Governance and the Challenge of Flexibility in East Asia, Lanham, Rowman and Littlefield Publishers: 137 - 164

Ernst, D. (2002a) 'Global Production Networks and the Changing Geography of Innovation Systems. Implications for Developing Countries, Journal of the Economics of Innovation and New Technologies XI (6): 497 -523

Ernst, D. (2002b), The Economics of Electronics Industry: Competitive Dynamics and Industrial Organization, In Lazonick W (ed.), The International Encyclopedia of Business and Management (IEBM), Handbook of Economics, London: International Thomson Business Press: 319-339 
Ernst, D., (2003a) Digital Information Systems and Global Flagship Networks: How Mobile is Knowledge in the Global Network Economy? In: J.F. Christensen and P. Maskell (eds.), The Industrial Dynamics of the New Digital Economy, Cheltenham, Edward Elgar

Ernst, D., (2003b), How Mobile is Knowledge in Global Digital Flagship Networks?, International Journal of Networking and Virtual Organizations. Special issue on Managing Knowledge in Virtual Organizations. Volume/part/pages

Ernst, D., (2003c) The New Mobility of Knowledge: Digital Information Systems and Global Flagship Networks. In: Latham, R. and S. Sassen (eds.), Digital Formations in a Connected World, published for the U.S. Social Science Research Council, London, Routledge.

Ernst, D., (2003d) Global Production Networks and Industrial Upgrading - A Knowledge-Centered Approach. In: G. Gereffi, (ed.), Who Gets Ahead in the Global Economy? Industrial Upgrading, Theory and Practice. Baltimore, Johns Hopkins University Press

Ernst, D., (2003e) Global Production Networks in East Asia's Electronics Industry and Upgrading Perspectives in Malaysia. In: S. Yusuf (ed.), Upgrading East Asia’s Industries, Vol. 2, Oxford University Press

Ernst, D., (2003f) The Economics of Global Electronics Design Networks, EastWest Center Economic Working Paper Series, \#56

Ernst, D. and O'Connor, D., (1992) Competing in the Electronics Industry. The Experience of Newly Industrialising Economies, Development Centre Studies, Paris, OECD 
Ernst, D, T. Ganiatsos and L. Mytelka (eds.) (1998) Technological Capabilities and Export Success - Lessons from East Asia. London, Routledge Press

Ernst, D. and L. Kim (2002a) Global Production Networks, Knowledge Diffusion and Local Capability Formation. Research Policy. Special issue in honor of Richard Nelson and Sydney Winter, 31 (8/9)

Feenstra, R., (1998) Integration of Trade and Disintegration of Production in the Global Economy, The Journal of Economic Perspectives, 12 (4): 31-50

Hirschman, A.O., (1958) Strategy of Economic Development, New Haven, Yale University Press

Hobday, M., (1995) Innovation in East Asia: The Challenge to Japan, Aldershot, Edward Elgar

Jones, R. and H. Kierzskowski, (2000) A Framework for Fragmentation. In: S. Arndt and H. Kierzkowski (eds.), Fragmentation and International Trade, Oxford, Oxford University Press

Lall, S., (1997) Technological Change and Industrialization in the Asian NIEs: Achievements and Challenges. A paper presented at international symposium on

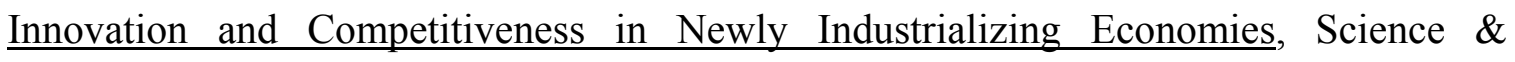
Technology Policy Institute, Seoul, Korea, May 26-27.

Magaziner, I. and M. Patinkin, (1989) Fast Heat: How Korea Won the Microwave War, Harvard Business Review, January-February: 267-308

MIDA - Malaysian Industrial Development Authority. (1999) Malaysia's Manufacturing Sector - into an Era of High Technology, Kuala Lumpur 
Ministry of International Trade and Industry, (1996) Second Industrial Master Plan, Kuala Lumpur, Malaysia

Multimedia Development Corporation (2002) Unlocking the Full Potential of the Information Age, available at http://www.mdc.com.my/package/

National Information Technology Council (NITC) (2002) Proceedings of NITC K-Strategy Policy Roundtable Dialogue, Kuala Lumpur, 23 November

Navaretti, G.B., J.I. Haaland, A. Venables, (2002) Multinational Corporations and Global Production Networks: The Implications for Trade Policy, Directorate General for Trade, European Commission, Brussels, March

Pavitt, K., (2002) Are Systems Designers \& Integrators "Post-Industrial” Firms? In A. Prencipe, A. Davies, M. Hobday (eds), Systems Integration and Firm Capabilities, Oxford, Oxford University Press

Porter, M., (1990) The Competitive Advantage of Nations, London, Macmillan

Prystay, C., (2001) Malaysia Seeks to Lift Super Corridor, Asian Wall Street Journal, August 24

Rasiah, R., (1995) Foreign Capital and Industrialization in Malaysia, London, St. Martin's Press

Rodrik, D., (1999) The New Global Economy and Developing Countries: Making Openness Work, Overseas Development Council Policy Essay No.24, Baltimore, MD., Johns Hopkins University Press

Rugman, A.M. and J. R. D'Cruz, (2000) Multinationals as Flagship Firms. Regional Business Networks, Oxford, Oxford University Press 
Saxenian, A., (2002) The Silicon Valley Connection: Transnational Networks and Regional Development in Taiwan, China and India. In special issue on Global Production, guest editors: D. Ernst and Linsu Kim, Industry and Innovation, 9 (2): 1832002

State Government of Penang, (2001) The Second Penang Strategic Development Plan, 2001 - 2010, Penang, Malaysia

Sturgeon, T. and R.K. Lester, (2003) Upgrading East Asian Industries: New Challenges for Local Suppliers. In S. Yusuf (ed.), Upgrading East Asia's Industries, Vol. 2, Oxford University Press

Takeuchi, J., (1993) Foreign Direct Investment in ASEAN by Small- and Medium-Sized Japanese Companies and its Effects on Local Supporting Industries, RIM.Pacific Business and Industries, Vol. IV, \#22. Center for Pacific Business Studies, Tokyo, Sakura Institute of Research

Takeuchi, J., (1997) The New Industrialization Strategy of Malaysia as Envisioned in the Second Industrial master Plan", RIM Pacific Business and Industries, Vol. III (37), Center for Pacific Business Studies. Tokyo, Sakura Institute of Research,

Too, T. and T.P. Leng, (2002) Unemployment Situation in Penang, Economic Briefing to the Penang State Government, 4 (4), Socio-Economic \& Environmental Research Institute (SERI), Penang, Malaysia

Tselitchtchev, I., (2003) East Asian Economies: Westernization, Liberalism, Regionalism, in this volume 